\title{
Dynamics of change in internal policy advisory systems: the hybridization of advisory capacities in Germany
}

\author{
Sylvia Veit, Thurid Hustedt, Tobias Bach
}

This is the post-print (i.e. final draft post-refereeing) version of the following article:

Veit, S., Hustedt, T., \& Bach, T. (2017). Dynamics of change in internal policy advisory systems: the hybridization of advisory capacities in Germany. Policy Sciences, 50(1), 85-103. https://doi.org/10.1007/s11077-016-9266-9

\begin{abstract}
Recent scholarship on advisory systems has focussed on the externalization of advisory capacities and sectoral dynamics of change, whereas changes of internal policy advisory systems have not yet been approached systematically. This article proposes an analytical concept for exploring change dynamics in internal policy advisory systems by means of three logics for assessing policy advice (political salience, credibility and representativeness). The approach is illustrated by analyzing changes within the internal policy advisory system of the German federal government (1990-2015). The analysis relies on three original datasets on ministerial departments, research agencies and governmental advisory bodies. We find that the internal advisory system of the German federal government is characterized by a differentiated hybridization of advisory logics, which has changed the nature of policy advice.
\end{abstract}

\section{Introduction}

Policy advisory systems - the organizational configuration of policy advisory actors in a jurisdiction or a policy sector (Halligan 1995) - are crucial for understanding the dynamics of policy-making (Campbell and Pedersen 2014; Peters and Barker 1993). Over the last decades, long-established advisory systems in various countries have increasingly become polycentric (Craft and Howlett 2013). As a consequence, the permanent bureaucracy's privileged position in providing policy advice is challenged by external advisors such as private consultants and think tanks (van den Berg, this issue) and political advisors with direct access to the minister (e.g. Eichbaum and Shaw 2010). As research on changes in advisory systems typically focuses on single policy domains (Heinrichs 2005; Hustedt 2013b), single types of advisory actors (Fobé et al. 2013; Metz 2013), or externalization (Migone and Howlett 2013; Vesely 2013), the change dynamics of internal policy advisory systems are poorly understood. This article contributes to filling this gap by asking whether and how the internal advisory system of the German federal government has changed over the course of the last 25 years. 
Whereas most scholarship focusses on cases where deliberate reforms of advisory systems have taken place (e.g. Australia, New Zealand), the German case displays limited reform activity. Although distinct advisory actors have been subject of public debate - such as the perceived widespread use of ad hoc commissions under Chancellor Gerhard Schröder (Siefken 2007) - there have been no reform attempts directed at the overall advisory system. Deliberate reforms tend to be sectoral in nature, addressing perceived shortcomings of individual organizations, rather than the entire administrative apparatus (Bach and Jann 2010). This suggests that transformations of the internal advisory system in Germany are likely to be incremental, reflecting gradual adaptations of organizations to changing environmental demands as well as deliberate reforms of single advisory actors.

Our empirical analysis covers the development of three types of internal advisory actors from 1990-2015: federal ministries, research agencies and advisory bodies. The article draws on three original datasets containing information on the career paths of ministerial senior civil servants and chief executives of research agencies, as well as the mandates and composition of governmental advisory bodies. To track the dynamics of change, we assess these actors' advisory capacities based on three logics: political salience, credibility and representativeness (Cash et al. 2003). As a result of adaptational pressures to exogenous processes affecting national policy advisory systems around the world such as mediatization and scientization, we expect a hybridization of advisory logics in internal policy advisory systems as the dominant change dynamic. The main focus is on the 'big picture' by tracking developments of key actors of the advisory system over time. Interdepartmental differences are analyzed, however, to investigate if change dynamics vary across policy sectors (Craft and Wilder 2015).

The next paragraph outlines the notion of internal policy advisory system and elaborates our theoretical argument, which is rooted in neo-institutional organization theory. After introducing the research design and methods, we present the empirical results. Finally, we discuss the implications of our findings for the study of change dynamics in policy advisory systems.

\section{Policy advisory systems, institutional logics, and change dynamics}

The concept of policy advisory systems as coined by Halligan (1995) distinguishes advisory actors as to their location (internal or external to government) and their exposure to government control (high or low). This locational approach assumes that internal actors are privileged over external actors in providing advice to government (Halligan 1995, p.150) According to Halligan (1995), the internal category comprises the public service, in particular the senior level, as well as temporary and permanent policy units, legislatures and "statutory authorities" (p.141), while private consultants, non-governmental organizations, organized interest groups and international organizations belong to the external category. He concedes, however, that what exactly comprises the "internal-to-government group" (Halligan 1995, p.140) is contingent upon the political system under study. 
The bottom line of a systems view on policy advisory arrangements is that analyzing single actors yields an incomplete picture of the realities of policy advice. Moreover, such a view implies that different types of actors contribute different advisory capacities thus providing specific types of policy advice. By calling for a "second wave" of policy advisory systems research, Craft and Wilders argue - among others - for a broader view on policy advice as "an activity that applies to a range of policy work" (Craft and Wilder 2015, p.6). In contrast to a narrow concept of policy analytical capacity with a focus on the generation of knowledge about the implications of alternative policy choices (Parrado 2014), policy advice includes both technical and political elements, the latter referring to gauging of consequences for political support and media reactions of policy alternatives (Craft and Howlett 2013).

Accordingly, this article refers to different types of policy advice based on distinct logics. Drawing on Cash et al. (2003), we distinguish three distinct logics that are present in any policy advisory system: salience, credibility, and representativeness. ${ }^{1}$ First, salience denotes the relevance and timeliness of advisory knowledge for policy-makers. Second, credibility refers to whether the production of knowledge follows established epistemological standards, i.e. whether it is scientifically robust. Third, representativeness denotes whether knowledge is produced in an unbiased way by considering all relevant interests (Cash et al. 2003). ${ }^{2}$ To operationalize these logics, we define policy advisory capacities as the availability of skills and organizational resources devoted to the provision of advice according to the three logics.

\section{Theoretical background}

A systems view suggests that all three types of logic need to be present in a given advisory arrangement (system). Moreover, the three logics constitute normative principles of collective decision-making, such as the majority principle in democratic governance, the notion of rational decision-making based on expert information, and the pluralist principle of considering affected interests (Gornitzka and Sverdrup 2011). The starting point is that different actors in advisory systems reflect the abovementioned logics to a different degree dependent on the location of an organization and on institutional factors that affect the type of expertise being provided. Organizational proximity to executive politicians, for instance, coincides with a high relevance of the logic of salience in an organization's advisory activities. In general, ministry officials will thus pay more attention to political priorities than their 'more remote' colleagues, for example in structurally disaggregated agencies (Egeberg and Trondal 2009).

\footnotetext{
1 These three logics were originally developed for scientific policy advice. We argue, however, that they are also relevant for policy advice in a broader sense. To be sure, not all policy alternatives conform to standards of scientific credibility, but at the very least they need to be based on plausible means-end assumptions.

2 Cash et al. (2003) use the term "legitimacy" for the third dimension. We use the term "representativeness" instead, as legitimacy may be relevant for any of the three standards.
} 
In a neo-institutionalist perspective, changes in the institutional environment create pressure for adaptation because organizations strive for generating and retaining legitimacy, leading to more similarity among organizations in a field as they similarly respond to environmental institutional expectations (Powell and DiMaggio 1991). However, research has shown a considerable degree of organizational heterogeneity due to mechanisms such as bricolage and translation (e.g. Campbell 2004). Moreover, organizations also adapt to diffuse institutional environmental changes that do not prescribe particular models (Campbell 2004). Accordingly, organizational change reflects environmental institutional change that can be diffuse or at times even inconsistent, but creates adaptation needs for the sake of legitimacy. Various and diffuse environmental pressures can have a selective effect on organizations, i.e. affecting different organizational parts in varying ways and thus result in a differentiation of internal roles and prevailing orientations. Following this line of reasoning, the paper conceives change dynamics in advisory systems as a response to exogenous processes that put the system's pre-existing composition and logic(s) under pressure. Accordingly, internal advisory actors will not only adhere to the traditional organizational logic (e.g. salience in ministries) but also respond to external developments by incorporating other advisory logics to generate and sustain legitimacy (Powell and DiMaggio 1991).

Current research sketches out various exogenous processes affecting policy advisory systems. Based on the literature we assume that three processes - the increasing significance of 'wicked problems', scientization and mediatization - are relevant drivers of change in the internal advisory system of the German federal government (Weingart and Lentsch 2008; Hustedt 2013c). ' 'Wicked problems' such as climate change or mass migration are characterized by simultaneously high levels of complexity, uncertainty and ambiguity (Head 2008). They are said to challenge policy-making as they involve considerable coordination by a wide range of actors from different sectors and levels of government and severe contestation with regard to potential policy solutions (Head 2008, Head and Alford 2015). Because of unclear and contested means-end relations, their concrete implications are virtually impossible to predict. Therefore policy solutions are difficult to agree upon, inducing governments to include a wide variety of actors and interests in the process of looking for potential solutions. Therefore 'wicked problems' potentially push representativeness as an increasingly relevant logic of policy advice.

Likewise, scholars have observed a growing importance of scientific evidence in policy-making (Jasanoff 1990; Hoppe 2005). The use of scientific arguments to underpin policy choices (or to question others' policy choices) has become part and

\footnotetext{
3 Other potentially relevant drivers of change in policy advisory systems include democratization (e.g., Fischer 1993) and administrative reforms (Van den Berg, this issue). Democratization is typically reflected in procedural changes such as online consultations and stakeholder fora and a greater openness of advisory communities. Its effects on the advisory organizations' institutional logics can - by definition - not be investigated by focusing on elite characteristics. This is a limitation of our analytical approach. Managerial reforms resulted in an increasing fragmentation of the public sector which - in particular, but not restricted to - in Westminster countries was accompanied by a hollowing out of internal advisory capacities fostering externalization (Halligan and Craft, this issue, van den Berg, this issue). For the federal administration in Germany the relevance of managerial reforms was, however, very limited (Bach and Jann 2010).
} 
parcel of policy-making (Weingart and Lentsch 2008; Straßheim et al. 2015). Hence, scientization emphasizes credibility as a relevant advisory logic.

Mediatization refers to the increasing incorporation of a media logic into other societal spheres including the public sector, which arguably prompts demands by politicians for media-related advice (Eichbaum and Shaw 2010; Hustedt 2013a). Mediatization fosters governmental actors to devote attention on how they are perceived by the media, to include considerations on how to 'sell' policies from the initial stages of policy preparation and prompts government to react much quicker to media coverage (Fredriksson et al. 2015). Mediatization also implies that internal advisory actors may become increasingly 'visible' to the public as distinct from the government. This suggests that mediatization strengthens the demand for salient advice in the policy advisory system.

We assume a differentiated impact of these three trends on the internal policy advisory system in Germany, The next section briefly outlines this system. Subsequently, we discuss in more detail which kind of change dynamics we expect to find in the German system.

\section{The internal advisory system of the federal government}

For the German federal government, we consider ministries, research agencies and advisory bodies as comprising the internal advisory system. The main function of federal ministries is policy formulation and law drafting since most implementtation tasks are delegated to the federal states (Länder). Based on their expertise, ministerial officials give policy advice, but are also in many ways on the receiving end of advice (e.g. via ad hoc commissions, contracted research) by collecting and processing most information for policy decisions. Federal ministries have traditionally had a strong role in policy formulation, although recent research has indicated a decreasing influence of the formerly very powerful working units (Goetz 2007). The basic principles of ministerial policy advice are lawfulness, policyexpertise and political responsiveness. The first two principles are mirrored in the merit career civil service system with low inter-sectoral mobility, and in a preference for recruiting candidates with a law degree (Derlien 2003). The latter principle is reflected by the high functional politicization of senior civil servants, meaning that those officials take political considerations (such as whether a policy alternative is likely to get parliamentary support) into account (Hustedt 2013a). Moreover, party membership of civil servants is widely accepted (Jann and Veit 2015). The two highest hierarchical ranks in federal ministries can be dismissed at any time and are regularly replaced by incoming ministers (Derlien 2003).

Most federal ministries have several research agencies operating within their portfolio that perform tasks requiring scientific training and methods (Weingart and Lentsch 2008). Those activities are usually combined with regulatory functions and policy advice to decision-makers (Bach and Döhler 2012). The latest government report lists 43 research agencies and similar organizations (BMBF 2014). Research agencies are hierarchically integrated into ministerial portfolios (Bach and Jann 2010). However, the authority of ministries to instruct agencies with regard to 
research activities is contested, and there is large variation in research agencies' actual autonomy from their parent departments (Weingart and Lentsch 2008). Surprisingly, research agencies have only recently been 'discovered' as relevant policy advisory actors. First, research agencies have become more visible in public, often related to crises such as in the area of consumer protection (Korinek and Veit 2015). Second, a comprehensive evaluation initiated by parliament scrutinized the quality of research agencies' scientific activities (German Science Council 2007) and recommended a more autonomous position of the agencies vis-à-vis their parent ministries (Bach and Döhler 2012). The evaluation triggered a debate about the type of research needed for policy-making and the relevance of high quality research for sound policy advice (Bach et al. 2013).

Germany has a long-standing tradition for the establishment of advisory bodies to the government with some of today's advisory bodies established shortly after the end of WWII. In particular since the early 1990s, incoming governments have frequently restructured the landscape of advisory bodies (Fleischer 2015). These bodies mostly deliver advice to single ministries, but some also report to several ministries or to federal agencies. The landscape of advisory bodies has always been complex with substantial variation in terms of members, budget, and mandates. As part of this variety, advisory bodies have different names, most prominently 'advisory councils' (Beiräte) or 'expert commissions' (Sachverständigenkommissionen). The denomination, however, does not indicate any ordering structure with regard to membership or mandate. There are both bodies staffed exclusively with academics, but also mixed bodies with representatives from various societal areas (including representatives of various ministries, agencies or federal states) and bodies purely staffed with representatives of organized interests. Members of advisory bodies are usually appointed on an honorary basis by the ministry. The work of advisory bodies is often supported by an office staffed with civil servants. It is exactly because of those characteristics that we include federal advisory bodies into the "internal-to-government group" (Halligan 1995, p.140). Relative to external policy advisory actors such as think tanks, they are much closer to the government, yet independent in their advisory content.

\section{External pressures and change dynamics}

What kind of change do we expect for the three actors of the internal policy advisory system in Germany? As already said, functionally politicized ministry officials are likely to pay most attention to political priorities, which underlines the importance of salience for bureaucratic decisions. Accordingly, the logic of salience - i.e. providing politically robust advice - is assumed to be at the core of ministerial policy advice. That said, mediatization has arguably increased the pressure on ministries to deliver politically robust advice on short notice (Thorbjørnsrud et al. 2014). We therefore predict a further growth in the relevance of salience for advice by ministry officials in the time period under study. We also expect ministries to increasingly reflect the logic of representativeness because of the growing relevance of 'wicked problems' and the necessity to legitimize policy decisions under the conditions of contested knowledge and uncertainty. In contrast, scientization is hypothesized to 
play a smaller role for advice by ministries, because ministries may turn to research agencies and external scientific advisors when needed.

Research agencies represent a distinct organizational solution to integrate scientific expertise into the government apparatus, which potentially creates tensions between political priorities transmitted through the hierarchical principle and research agencies' following of epistemological standards (Bach et al. 2013). To give credibility considerations a higher priority was a key element of the recent evaluation exercise, suggesting that the logic of credibility has become more important for research agencies. However, without considering political priorities, research agencies risk drifting away from the needs of their sponsoring ministries, which may turn to other, more responsive sources of policy advice. Therefore, research agencies have to be responsive to political demands to be considered relevant advisory actors. Although there seems to be an inherent trade-off between credibility and salience as institutional logics, research agencies may simultaneously provide policy relevant advice and perform high quality research as a result of internal specialization and coordination procedures to ensure that research activities are in line with the agency's mandate (Bach et al. 2013). Thus, we expect hybridization dynamics involving a simultaneous increase of both credibility and salience in research agencies' advisory profile.

Honorary appointments in advisory bodies and the affiliation of committee members with either scientific organizations or organized interests are likely to stress credibility or representativeness as dominating logics, depending on the composition of a specific advisory body. Thus, we argue that advisory bodies typically focus on either credibility or representativeness in providing advice, depending on their mandate and composition. While we assume that either logic dominates single advisory bodies, we expect that pure types have lost in relevance and are increasingly supplanted by advisory bodies seeking to accommodate advice that is simultaneously credible and representative and incorporates "negotiated, multi-source expertise" (Krick 2015, p.487). As scientific advice has gained in relevance, we expect that advisory bodies will more and more reflect the logic of credibility by including scholars among their members. Particularly when it comes to 'wicked problems' scientific knowledge is uncertain and contested, and advice needs to be acceptable to various, often fragmented social groups or interests. Krick (2015, p.489) argues that advisory bodies composed of both academics and representatives of interest organizations are "very powerful instruments of governance" because they match the governmental demands to address complex, at times contradictory conditions for policy-making (see also: Jasanoff 2005). We expect that over time a growing share of advisory bodies integrates both the logic of credibility and the logic of representativeness.

\section{Research design and data collection}

The article analyzes three types of policy advisory actors in an innovative longitudinal research design spanning from 1990 to 2015 . While the empirical material for each type of advisory actor is somewhat different, the overall rationale is similar, namely to study advisory capacities as proxies for assessing the prevalence of the 
different advisory logics (see Parrado 2014 for a discussion of methodological challenges in the measurement of advisory capacities). For ministries and research agencies, the relevance of different advisory capacities is assessed by exploring career backgrounds of senior civil servants (SCS). The appointment of SCS with a specific career background indicates what type of advisory capacity is deemed most relevant for an organization to perform its tasks and to ensure legitimacy (see Christensen and Lægreid 2009 for a similar argument).

For the ministries and research agencies, the empirical analysis is based on two comprehensive datasets comprising all SCS in the two highest hierarchical ranks (administrative state secretaries and directors-general) in federal ministries $(\mathrm{N}=589)$ and all agency heads $(\mathrm{N}=101)$ in the time period 1990-2015. The datasets comprise seven legislative periods (LP) of the federal parliament. For every individual we collected information on educational background and careers, based on the official government handbook, archive data, organization charts, official websites and media coverage. For the analysis of career patterns, we used descriptive measures like the duration of service in different sectors. The datasets do not include acting chief executives of agencies and individuals from the military part of the ministry of defence (including research agencies within the military).

The dataset on advisory bodies comprises information on their mandates and composition. The latter is considered to shed light on the particular knowledge contributed by the different types of members (see Gornitzka and Sverdrup 2011 for a similar approach). Typically established by law, statuary ordinance, decree or cabinet decision, formal mandates reflect the political expectations an advisory body is supposed to meet, i.e. it reveals the "expected function" (Weingart and Lentsch 2008, p.55). Whereas formal mandates vary in terms of the concrete prescription of tasks, composition and procedures (Weingart and Lentsch 2008, p.280), they indicate distinct functions attributed to advisory bodies by a political decision in the course of the establishment process (Mayntz 2009, p.10). Generally, their function is designated as either 'policy advice' or 'scientific policy advice'. This is also serving as the core distinction in our empirical analysis. As individual level data on the backgrounds of members of advisory bodies is unavailable for longer periods of time, the empirical analysis relies on two data sources: First, formal mandates of single advisory bodies are analyzed on the basis of government reports. ${ }^{4}$ Prescribed by the Federal Act on Appointment to Bodies (FAAB) and based on ministerial selfreporting these reports document the representation of women in advisory bodies and have been published once per LP, yet with irregular baseline years $(1991,1997$, $2001,2005,2009,2014^{5}$ ). A reform of the FAAB in 2015 made it mandatory for federal ministries to publish the respective information on their individual websites ( $₹ 7$ FAAB as of 2015). Data for the most recent LP is based on that information. Second, individual level data on the members of advisory bodies in 2015 were collected from the ministries' and advisory bodies' websites or ministerial press releases. Individual level information (in the vast majority of the cases) is only

\footnotetext{
${ }^{4}$ While the reports also include information on international or oversight bodies to which the federal ministries delegate representatives, the dataset only includes advisory bodies.

5 In 2014 a report was published including the figures that were supposed to inform the official governmental report, yet the latter has not yet been published (Kienbaum 2014).
} 
published for the current composition, thus making a retrospective analysis at the individual level impossible. That said, this data arguably represents the most encompassing and systematic data collection on advisory bodies to the German government so far. Across all LPs, the dataset includes 414 cases. ${ }^{6}$

\section{The differential hybridization of the internal advisory system}

The presentation of our empirical analysis is descriptive since we aim to illustrate how our analytical approach can be applied for describing changes in policy advisory systems. For each actor, we discuss in how far the (theoretically) expected direction of change is confirmed by our data.

\section{$\underline{\text { Federal ministries: high salience and more representativeness }}$}

As elaborated above, we expect a constantly high relevance of salience and an increasing relevance of representativeness - but not of credibility - in federal ministries. We measure salience by investigating the share of SCS with professional experience in the political sector (as party staff, parliamentary staff or member of parliament) and/or in civil service positions close to politics (press units, leadership staff units, personal assistants of a minister or SCS, secondment to the federal chancellery), because by working in these positions individuals acquire the advisory capacities necessary for giving politically robust policy advice.

The empirical analysis indeed reveals the high relevance of salience for SCS: In all seven LPs under study a large majority of SCS had experience in the political sector or in civil service positions close to politics. Over time, no clear trend is observable although it is remarkable that the two highest scores are in the most recent LPs ( $\sim 64 \%$ in LP17 and LP18). Compared to the 1990s, however, the growth is rather small (figure 1). A closer look at the single types of career positions that are relevant for salience (figure 2) sheds light on how important different kinds of 'salience capacities' are. Experience in press units, for instance, points to the demand for considering the media logic when giving policy advice, whereas experience at state level highlights advisory capacities related to the specific conditions of policymaking in the German system of cooperative federalism.

Three findings deserve special mentioning: First, work experience in the chancellery, in leadership staff units and as parliamentary staff is particularly widespread. This indicates that strategic knowledge about policymaking, e.g. about relevant actors and networks, is considered crucial for giving politically robust policy advice. ${ }^{7}$ Second, a remarkable development over time is the comparatively large increase in the share of former press spokesmen and staff members of press units (by 400\%) although the total share of this group still is on a rather low level ( $10 \%$, figure 2$)$. Thus, media-related capacities have grown in importance in the last 25 years. Third,

\footnotetext{
${ }^{6}$ We include cases per LP, hence advisory bodies can be counted more than once.

7 The relevance of work experiences as parliamentary staff (often while being 'on leave' from the ministry) points out that partisan loyalty also plays a role as selection criteria for SCS. This does, however, not contradict our approach of considering advisory skills gathered in the course of different career steps as proxies for advisory logics since research has shown that ministers appoint SCS who are both loyal and possess relevant qualifications (Veit and Scholz 2016).
} 
an growing share of SCS has work experience at state level (mostly in state ministries), showing that knowledge on the functioning of the federal system is an important capacity for SCS in federal ministries.

\section{Figure 1}

Figure 2

Studying sectoral dynamics, we find that the prevalence of salience differs across ministries. It might be little surprising that this type of expertise is particularly important in the chancellery $100 \%$ SCS with political experience in all LPs under study) and comparably less important in the ministry of justice (always less than $50 \%$ ) where legality is a central criterion for ministry officials' work. Over time, the importance of salience neither clearly increases nor decreases in most ministries, with three exceptions: In the ministry of foreign affairs, the importance of salience has been (almost) constantly growing, from 50\% LP12 to 93\% in LP18. For the ministry of economics, a similar trend exists (33\% in LP12 to 63\% in LP18). Both ministries are responsible for the coordination of EU policy-making which might explain these developments. The ministry of environment shows a similar increase in salience (27\% in LP12 to $46 \%$ in LP18) reflecting an adaptation to the level of other ministries since this ministry is the 'youngest' one at federal level (founded in 1986). A contrary development exists in the ministry of finance where salience lost in importance over time - however still on a high level (77\% in LP12 to 58\% in LP18). Whether this finding indicates a loss of power of the ministry is a question that should be addressed in future research. To sum up, despite some variation across ministries and over time, salience capacities have proven to be important in all ministries.

Turning to representativeness, a more clear-cut picture emerges. Representativeness is measured by the share of mixed careers thereby assuming that SCS with more diverse career backgrounds are better trained to take different perspectives than SCS with a pure civil service or single sector career. Our analysis reveals that over time the share of SCS with mixed careers almost doubled between 1990 and 2015. In recent years, one fourth to one third of SCS had a mixed career background in at least two sectors (figure 1). This increase can be observed very clearly in almost all ministries.

To examine the role of credibility in ministerial policy advice, we analyze the share of SCS with professional experience of more than four years in academia. All in all, SCS with a career in academia are rather seldom. Their share was less than $5 \%$ in the first two LPs under study, doubled in LP14-16 and decreased again to less than $5 \%$ in the two most recent LPs (figure 1). Comparing ministries two findings emerge: First, the chancellery is much more "academic" than the other ministries: In the different LPs under study 10\% (LP17) to 62.5\% (LP14) of the SCS in the chancellery had a career background in academia. Second, in the first two LPs under study, SCS with an academic career were concentrated in only three ministries (chancellery, ministry of finance, ministry for education, science, research and technology) whereas later on it has become much more common to recruit SCS with a background in academia also in other ministries. This is - because of the rather low total share of SCS with an academic career - no sign for an increasing relevance of 
the logic of credibility, but confirms our findings as to representativeness: ministries have obviously become more open for candidates with mixed career experiences.

Summing up, the empirical analysis reveals changes in the importance of the three advisory logics over time confirming our theoretical expectation of hybridization: Salience still is the most prominent advisory logic for ministries. Credibility is of rather low significance for ministerial work. Representativeness, however, has become more influential.

\section{$\underline{\text { Research agencies: more credibility and high salience }}$}

Our expectation for research agencies is a simultaneous increase in both credibility and salience as criteria for the selection of senior staff. To investigate this claim, we analyze career backgrounds of chief executives at the time of their appointment. A career background in academia (also in combination with employment in administration or other sectors) is considered as a proxy for the logic of credibility. Those careers are contrasted with administrative careers (as a proxy for salience), also including combined careers in other sectors, though excluding positions in academia. Second, we investigated the position of chief executives immediately prior to their appointment. This information provides further clues as to the importance of different advisory capacities for recruitment decisions.

Looking at the entire period, we see a long-term trend of a growing proportion of recruitments of chief executives with a primarily academic career background (figure 3). ${ }^{8}$. The last period of observation (LP18) seems to be an outlier, which may be related to a comparatively low number of observations $(\mathrm{N}=5)$. A more finegrained analysis shows that the observed trend is primarily driven by an increasing proportion of recruitments of individuals with an academic career outside the core administration. In terms of sectoral variation, the growth in recruitment of candidates with an academic career background is evenly spread and visible in all sectors. The only exceptions here are agriculture, family affairs, and foreign affairs, where chief executives invariably have had an academic career upon their appointment throughout the period of observation.

\section{Figure 3}

Turning to the analysis of positions held prior to their appointment as chief executives we find a declining relevance of recruitments from federal agencies, most of which are recruitments from the appointing agency. This used to be the dominant mode of recruitment until LP14, after which other types of recruitment have become more prominent. There is no clear trend with regard to recruitment from ministerial positions, which has never been the most important way of recruitment, with the exception of the last period of observation, which should be treated with caution. Taken together, however, recruitments from administrative positions, i.e. either from ministries or federal agencies, are clearly the dominant mode of recruitment (more than $50 \%$ in all LPs) (figure 4). Finally, we see no continuous trend towards more

\footnotetext{
8 The analysis focuses primarily on the period beginning with LP12, as the data for recruitments in previous years are biased due to the sampling strategy (only those individuals recruited before LP12 which are still in office in LP12 are included in the dataset).
} 
chief executives being recruited directly from academic positions over time. To be sure, there is a jump in the data in LP15 and LP16, which supposedly is related to the reform debate surrounding the evaluation of research agencies that peaked during this period. However, in subsequent observation periods, the share of recruitments from academia is declining again. These observations refine the above finding on the growing relevance of academic careers. The apparent trend of scientization in research agencies is driven as much by the recruitment of people with mixed career including academic and administrative positions as by the recruitment of 'pure' academics.

\section{Figure 4}

Taken together, we observe a trend towards the strengthening of advisory capacity of the credibility type, as indicated by an increasing recruitment of individuals with an academic background. Mixed academic and administrative experience continues to be highly relevant. This is obvious in LP17, which is almost completely dominated by recruitments of individuals with an academic career background (figure 3), yet with a decline in direct recruitment from academia (figure 4). That said, we also find that previous employment in a ministry is (and has always been) widespread, though less common than previous employment in a federal agency. Arguably, both types of positions are relevant training grounds for acquiring an understanding of political criteria of decision-making, though ministries more so than agencies (Egeberg and Trondal 2009). For research agencies, the recruitment of individuals with administrative experience - i.e. with advisory capacity related to salience - has always been important. This capacity has become supplemented with advisory capacity of the credibility type over time. Yet the latter often comes in a hybrid form, as part of a mixed career with administrative employment spells, although the recruitment of individuals with a pure academic career background also has become more common.

\section{Advisory bodies: more representativeness}

As elaborated above, we assume a hybridization of the logics of representativeness and credibility as the prevalent logics according to which advisory bodies are mandated and their members appointed. Departing from a traditional focus on either the logic of credibility or representativeness, we expect over time that advisory bodies increasingly and simultaneously adhere to both logics. The prevailing logics are assessed at the organizational level by examining the formal mandates of advisory bodies, and by looking at the actual composition of advisory bodies as of 2015 at the individual level. First, a rising number of advisory bodies with a formal mandate defining 'policy advice' as the task of an advisory body would indicate hybridization, because formal mandates are either specified as 'scientific policy advice' or broader and more generally as 'policy advice'. Second, if members of advisory bodies are increasingly both academics and representatives from societal organisations, this would also indicate hybridization. Third, if academics are represented in mixed bodies, we would assume that both logics are actually adhered to, as they add credibility to the advisory body. The following analysis depicts the advisory bodies existing in the respective LPs. 
By analyzing the formal mandates over time, we indeed find that, across all LPs, advisory bodies established to provide 'policy advice' represent the majority that is growing until LP15 (2002-2005) and afterwards stabilizing on a level considerably higher than in the early 1990s (figure 5). For advisory bodies mandated to provide 'scientific advice', we find a modest increase. There are only very few advisory bodies with mandates other than scientific or policy advice throughout the whole study period. The growth in the existence of 'policy advisory bodies' in LP14 and LP15 can be traced back to the political desire of the red-green coalition government under chancellor Gerhard Schröder to establish advisory bodies for 'hybrid motivations' i.e. for transferring knowledge but also - maybe even more important - for finding consensus. As the chief of staff at the chancellery at the time Frank-Walter Steinmeier wrote in 2001: "Advisory bodies serve to provide an understanding of the issue at stake, the formulation of policy objectives and the mutual consent on particular corridors to address the issue" (Steinmeier 2001, p.266, translation by the authors). Regarding sectoral variation, the trend towards an increasing share of advisory bodies mandated to provide policy advice is almost evenly spread across sectors. However, from LP17 onwards between 16\% (LP18) and 20\% (LP16) of all policy advisory bodies are established in the realm of the ministry of labour, which might indicate a traditional pattern of corporatism that entered the arena of advisory bodies. Overall, the trend towards `policy advice`-mandates can serve as a first indication for hybridization.

\section{Figure 5}

The analysis of individual level data strengthens the indication that advisory bodies represent hybrids: While $64 \%$ of all advisory bodies in 2015 represent a mixed membership, only 24\% (science) and 12\% (society), respectively, are exclusively staffed with either academics or societal representatives (Figure 6). This finding of a hybrid landscape of advisory bodies is supported by the representation of academics in the mixed bodies: In 2015, the share of academics amounts to $29 \%$ (mean value) in the mixed groups, hence on average almost every third member of a mixed body is an academic. However, here we find substantial variation, as the minimum is $3 \%$ and the maximum $92 \%$. Case study research on the internal dynamics of advisory bodies shows that the internal composition matters for the production of advice and the role perceptions: While purely scientific bodies emphasize scientific independence as their "holy grail" (Weingart and Lentsch 2008, p.65, FN 23) ultimately seeking to "build a bridge between science and politics" (Hustedt 2013b, p.104), academics in mixed bodies can develop more into mediators between conflicting perspectives (Suda 2007, p.142). Mixed bodies can also serve as an "advocacy body" of the issue at stake as, e.g., in the case of the Council for Sustainable Development (Hustedt 2013c, p.53).

\section{Figure 6}

To sum up, the analysis reveals that advisory bodies to the federal government today incorporate both the institutional logics of credibility and representativeness into their advice. Thus, advice provided by advisory bodies is representative, i.e. includes a variety of views of affected interests in a given area, and is simultaneously also somewhat 'confirmed' by academic credentials. Given the major share of mixed 
bodies, we cannot assume that the advice in those bodies is (or is expected to be) produced exclusively by following scientific standards, but it seems fair enough to conclude that the academics bring a good dose of credibility to the advice and fulfill a 'double-check' or 'watch-dog' function from the perspective of epistemological standards.

\section{Conclusion}

Our main finding is that all three actors of the internal advisory system in Germany indeed increasingly incorporate different types of institutional logics for giving policy advice. Hence, they are becoming more hybrid, albeit in different ways. We find a growing significance of the logic of representativeness in ministries while salience continuously is on a high level. Research agencies combine salience and credibility, with an increase in the latter. Advisory bodies more and more incorporate the logics of credibility and representativeness. These findings indicate the prevalence of actor-specific, hybrid institutional logics and provide a fine-grained picture of the internal configuration of the German policy advisory system. The supposedly strong connection between location and advisory content is becoming blurry over time (Craft and Howlett 2013). The analysis also confirms our hypothesis of incremental adaptations rather than radical changes in the German system.

Our findings on advisory bodies resonate well with the specific 'civic epistemology in Germany, Sheila Jasanoff (2005) found in her comparative analysis of policy advisory bodies in biotechnology policy. She argues that trust in expertise is generated by institutional representation or affiliation of experts in the German context. The various perspectives which are brought forward, deliberated and negotiated in rather closed advisory bodies thus represent "microcosms of society" (Jasanoff 2005, p.269). Critics have argued that Jasanoff's results can hardly be generalized because she only studies one particular policy domain and that her conceptual conclusions do not allow for the analysis of change (Straßheim 2013, p.76). Our results speak to this criticism as they take a cross-sectoral and crosstemporal perspective, suggesting that the current landscape of advisory bodies represent instances of Jasanoff's German civic epistemology by the hybrid incorporation of the institutional logics of credibility and representativeness, i.e. instances of encoding of authoritative knowledge-production grounded in broader traits of the political culture.

Since taking a bird's eye perspective on the dynamics of advisory systems may underestimate the variation between policy sectors, we also analyzed cross-sectoral variation. Yet, we did not find evidence for the observed developments being caused by changes in individual sectors. Moreover, there are almost no sectoral 'outliers' with another direction of change. Irrespective of the added value of a cross-sectoral systems perspective, the study produced novel empirical insights that might inspire future research. The relevance of different advisory logics across ministries and over time, for instance, suggests that there are shifts in the functions and the power of single ministries that deserve further attention. 
Given the longitudinal, cross-sectoral nature of the analysis, this study provides a stylized argument regarding the implications of potential drivers of change for internal advisory systems. These are conceived of as significant changes in advisory actors' environments that create adaptational pressures. How these pressures translate into change in different jurisdictions - through top-down reforms driven by executive politicians or senior officials, or through bottom-up changes via gradual adaptation or the layering of organizational structures and processes - constitutes an important area for future research.

By interpreting the findings from our study, readers must be cautioned on two fronts: First, by focussing on advisory logics expressed by individual and organizational advisory capacities, this study does not capture other aspects of change dynamics such as, e.g., modified procedures or interaction patterns (Craft and Wilder 2015). Second, conceiving larger societal trends as creating adaptational pressure ultimately reflected in individual advisory capacities does not allow for capturing other adaptations. For instance, Korinek and Veit (2015) showed that democratization has led to structural adaptations in the German food safety research agency that are not visible at the level of top civil servants' capacities.

Research on policy advice in general assumes that policy advice affects policy formulation and policy output (e.g. Peters and Barker 1993). However, as the specific influence of policy advice is extremely difficult to assess (Campbell and Pedersen 2014; Craft and Howlett 2012; Gornitzka and Sverdrup 2011), advisory characteristics are commonly studied as proxies for 'influence'. Craft and Howlett (2012: 83) argue that the content of advice provides a tentative answer to the question "influence over what?". In a similar vein, this article suggested to understand advisory capacities representing 'standards of policy advice' as proxies for influence because they will affect the content of advice. Hence, by emphasizing the advisory capacities of the different actors of the internal advisory system, our methodology provides an analytical approach for comparative and longitudinal studies on the efficiency of policy advisory systems. It is thus a useful step towards analyzing 'content', and ultimately 'influence', especially under conditions of polycentric advisory systems. To put it sharply: If ministries emphasize salience and (increasingly) representativeness we expect ministerial policy advice to be shortterm orientated and responsive to the political principal, and simultaneously legitimized by the consultation of relevant interests. If research agencies (increasingly) stress salience and credibility, their advice will be scientifically robust and potentially more geared towards long-term perspectives, but simultaneously adapted to political needs. If advisory bodies focus on credibility and representativeness, we can expect the content of policy advice to represent a 'pre-cooked' perspective on a policy issue at hand, in which potential opposition to particular suggestions has already been eliminated, which is why such advice can be used by governments to achieve consensus with relevant stakeholders (long) before the actual decision is made. 


\section{References}

Bach, T., Döhler, M. (2012). Mandated science and the problem of neutral expertise: The case of governmental research agencies. Berlin: WZB Discussion Paper SP III 2012-602.

Bach, T., Jann, W. (2010). Animals in the administrative zoo: organizational change and agency autonomy in Germany. International Review of Administrative Sciences, 76 (3), 443-468.

Bach, T., Barlösius, E., Döhler M., Philipps, A (2013). Governance von Ressortforschungseinrichtungen. In E. Grande et al. (Eds.), Neue Governance der Wissenschaft (pp.139-62). Bielefeld: Transcript.

BMBF (Bundesministerium für Bildung und Forschung) (2014): Bundesbericht Forschung und Innovation 2014, Berlin.

Campbell, J. (2004). Institutional Change and Globalization. Princeton/Oxford: Princeton University Press.

Campbell, J.L., Pedersen, O.K. (2014). The national origin of policy ideas. Princeton/Oxford: Princeton University Press.

Cash, D. W., Clark, W. C., Alcock, F., Dickson, N. M., Eckley, N., Guston, D. H., Mitchell, R. B. (2003). Knowledge systems for sustainable development. Proceedings of the National Academy of Sciences of the United States of America, 100 (14), 80868091.

Christensen, T., Lægreid, P. (2009). Living in the Past? Change and Continuity in the Norwegian Central Civil Service, Public Administration Review, 69 (5), 951-961.

Craft, J., Wilder, M. (2015). Catching a Second Wave: Context and Compatibility in Advisory System Dynamics. Policy Studies Journal, doi:10.1111/psj.12133.

Craft, J., Howlett, M. (2012). Policy Formulation, Governance Shifts and Policy Influence: Location and Content in Policy Advisory Systems. Journal of Public Policy, 32 (2), 79-98.

Craft, J., Howlett, M. (2013). The dual dynamics of policy advisory systems: The impact of externalization and politicization on policy advice. Policy and Society 32 (3), 187-197.

Derlien, H.-U. (2003). Mandarins or Managers? The Bureaucratic Elite in Bonn, 1970 to 1987 and Beyond. Governance, 16, 401-428.

Egeberg, M., Trondal, J. (2009). Political Leadership and Bureaucratic Autonomy: Effects of Agencification. Governance, 22 (4), 673-688.

Eichbaum, C., Shaw, R. (2010). Partisan Appointees and Public Servants. An International Analysis of the Role of the Political Adviser, London: Edward Elgar.

Fischer, F. (1993): Citizen participation and the democratization of policy expertise: From theoretical inquiry to practical cases. Policy Sciences 26 (3), 165-187.

Fleischer, J. (2015). Organisierte Expertise und die Legitimation der Verwaltung: Sektorale und strukturpolitische Dynamiken der Gremienlandschaft auf Bundesebene. dms - der moderne staat, 8 (2), 315-336. 
Fobé, E., Brans, M., Vancoppenolle, D., Van Damme, J. (2013). Institutionalized advisory systems: An analysis of member satisfaction of advice production and use across 9 strategic advisory councils in Flanders (Belgium), Policy and Society, 32 (3), 225-240.

Fredriksson, M., Schillemans, T. ,Pallas, J. (2015). Determinants of organizational mediatization: An analysis of the adaptation of Swedish government agencies to news media. Public Administration 93 (4), 1049-1067.

German Science Council (2007). Executive Summary: Recommendations on the Role and Future Development of the Governmental Research Agencies with R\&D Activities. Köln: Wissenschaftsrat.

Goetz, K. H. (2007). German Officials and the Federal Policy Process: The Decline of Sectional Leadership.In Page, E. C., Wright, V. (Eds.): From the Active to the Enabling State (pp.164-188). Basingstoke: Palgrave.

Gornitzka, Å., Sverdrup, U. (2011). Access of Experts: Information and EU Decisionmaking. West European Politics 34 (1): 48-70.

Halligan, J. (1995). Policy Advice and the Public Sector. In B.G. Peters \& D.T. Savoie (Eds.), Governance in a Changing Environment (pp.138-172). Montreal: McGillQueen's University Press.

Head, B. W. (2008). Wicked Problems in Public Policy. Public Policy, 3 (2), 110-118.

Head, B. W, Alford, J. (2015). Wicked Problems: Implications for Public Policy and Management. In: Administration \& Society, 47 (6), 711-739.

Heinrichs, H. (2005). Advisory systems in pluralistic knowledge societies: A criteriabased typology to assess and optimize environmental policy advice. In S. Maasen \& P. Weingart (Eds.), Democratization of Expertise? Exploring Novel Forms of Scientific Advice in Political Decision-Making (pp.41-61). Dordrecht: Springer.

Hoppe, R. (2005): Rethinking the science-policy nexus: from knowledge utilization and science technology studies to types of boundary arrangements. Poiesis \& Praxis, 3 (3), 199-215.

Hustedt, T. (2013a). Ministerialverwaltung im Wandel - Struktur und Rolle der Leitungsbereiche im deutsch-dänischen Vergleich. Baden-Baden: Nomos Verlag.

Hustedt, T. (2013b). Analyzing policy advice: The case of climate policy in Germany. Central European Journal of Public Policy, 7 (1), 88-110.

Hustedt, T. (2013c). Institutions and forms of knowledge: Organizing policy advice. In H. Lindberg (Eds.), Knowledge and Policy Change (pp.42-59). Cambridge: Cambridge Scholars Publishing.

Jann, W., Veit, S. (2015): Germany. In M. Van Wart et al. (Eds.), Leadership and Culture. Comparative Models of Top Civil Servant Training (pp.183-199). London/New York: Palgrave Macmillan.

Jasanoff, S. (1990). The fifth branch: science-advisors as policymakers. Cambridge, MA: Harvard University Press.

Jasanoff, S. (2005). Designs on nature: Science and democracy in Europe and the United States. Princeton: Princeton University Press. 
Kienbaum (2014). Datenreport „Vorbereitende statistische Analysen und Auswertungen zur Umsetzung des Bundesgremienbesetzungsgesetzes", im Auftrag des Bundesministeriums für Familie, Senioren, Frauen und Jugend. Berlin.

Korinek, R.-L., Veit, S. (2015). Only good fences keep good neighbours! The inistitutionalization of ministry-agency relationships at the science-policy nexus in German food safety policy. Public Administration, 93 (1), 103-120.

Krick, E. (2015). Negotiated expertise in policy-making: How governments use hybrid advisory committees. Science and Public Policy, 42 (4), 487-500.

Mayntz, R. (2009). Speaking Truth to Power: Leitlinien für die Regelung wissenschaftlicher Politikberatung. Der moderne Staat (dms), 2 (1), 5-16.

Metz, J. (2013). Expert groups in the European Union: A sui generis phenomenon? Policy and Society, 32 (3), 267-278.

Migone, A., Howlett, M. (2013): Policy advice through the market: The role of external consultants in contemporary policy advisory systems, Policy and Society, 32 (3), 241-254.

Parrado, S. (2014). Analytical Capacity. In M. Lodge \& K. Wegrich (Eds.), The Problemsolving Capacity of the Modern State (pp.86-104). Oxford: Oxford University Press.

Peters, B. G., Barker, A. (1993). Advising West European Governments: Inquiries, Expertise and Public Policy. Edinburgh: Edinburgh University Press.

Powell, W.W., DiMaggio P.J. (1991). The New Institutionalism in Organizational Analysis. Chicago: University of Chicago Press.

Siefken, S. T. (2007). Expertenkommissionen im politischen Prozess. Wiesbaden: VS Verlag für Sozialwissenschaften.

Steinmeier, F. W. (2001). Konsens und Führung. In F. Müntefering \& M. Machnig (eds.), Sicherheit im Wandel (pp.263-272). Berlin: Vorwärts-Verlag.

Straßheim, H. (2013). Politische Expertise im Wandel. Zur diskursiven und institutionellen Einbettung epistemischer Autorität. In: S. Kropp \& S. Kuhlmann (Eds.), Wissen und Expertise in Politik und Verwaltung. Sonderheft 1/2013, Der moderne Staat (pp.65-86). Opladen \& Toronto: Barbara Budrich.

Straßheim, H., Jung, A. and Korinek, R.-L. (2015). Reframing Expertise: The Rise of Behavioural Insights and Interventions in Public Policy, In: A. Berthoin Antal, M. Hutter \& D. Stark (Eds.) Moments of Valuation. Exploring Sites of Dissonance (pp.249-268). Oxford: Oxford University Press.

Suda, M. (2007). „Der Beirat ist ein Forum und das war schon immer so." Politikberatung durch Beiräte - Eine Fallstudie zum Obersten Naturschutzbeirat in Bayern. In: M. Krott \& M. Suda (Eds.), Macht Wissenschaft Politik? (pp.124-145). Wiesbaden: Springer.

Thorbjørnsrud, K., Ustad Figenschou, T., Ihlen, Ø. (2014). Mediatization in public bureaucracies: A typology. Communications - The European Journal of Communication Research, 39 (1), 3-22. 
Veit, S., Scholz, S. (2016). Linking administrative career patterns and politicisation. Signalling effects in the careers of top civil servants in Germany. International Review of Administrative Sciences, 82 (3), 516-535.

Veselý, A. (2013). Externalization of policy advice: Theory, methodology and evidence. Policy and Society, 32 (3), 199-209.

Weingart, P., Lentsch, J. (2008). Wissen - Beraten - Entscheiden. Weilerswist: Velbrück-Wissenschaft. 


\section{Figures}

Figure 1: Advisory capacities of ministerial SCS 1990-2015 (\% of all SCS per LP)

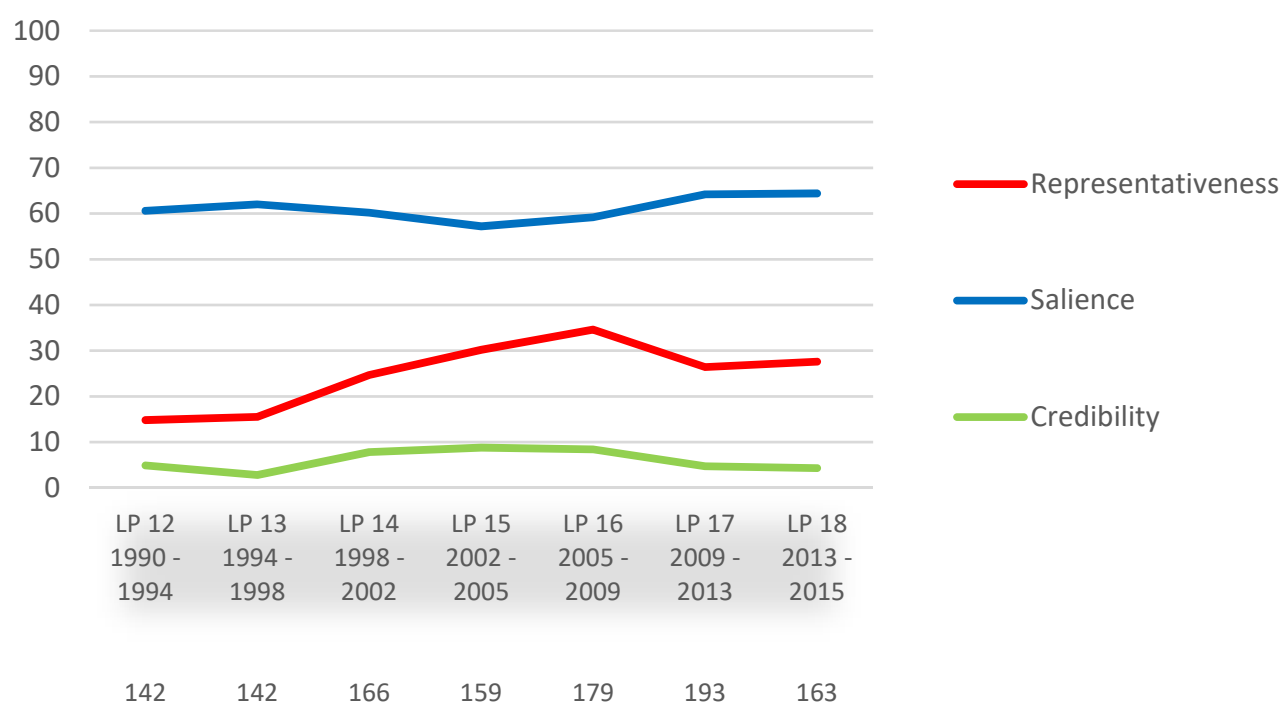

Numbers below: Absolute number $(\mathrm{N})$ of SCS per LP Source: Own data.

Figure 2: Work experience of ministerial SCS 1990-2015 (\% of all SCS per LP)

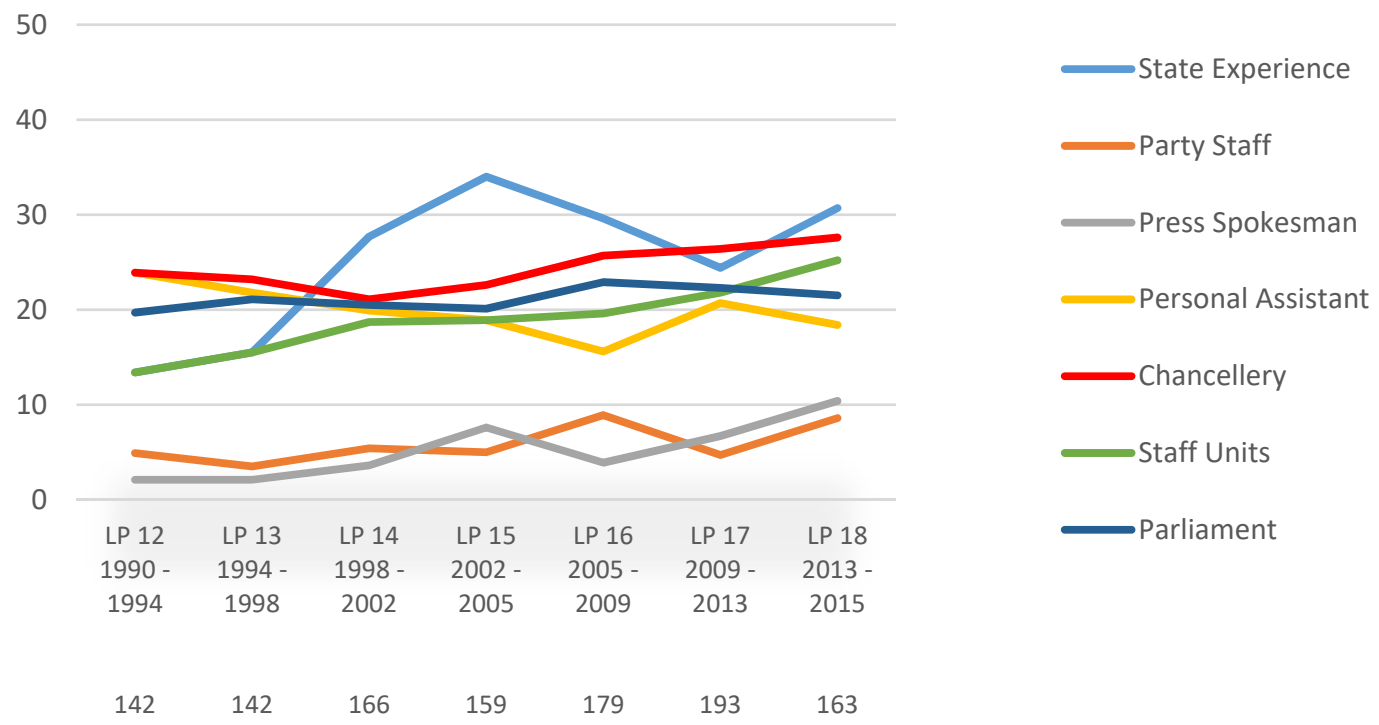

Numbers below: Absolute number (N) of SCS per LP. Source: Own data. 
Figure 3: Career background of chief executives of research agencies (\% of all CEO per LP)

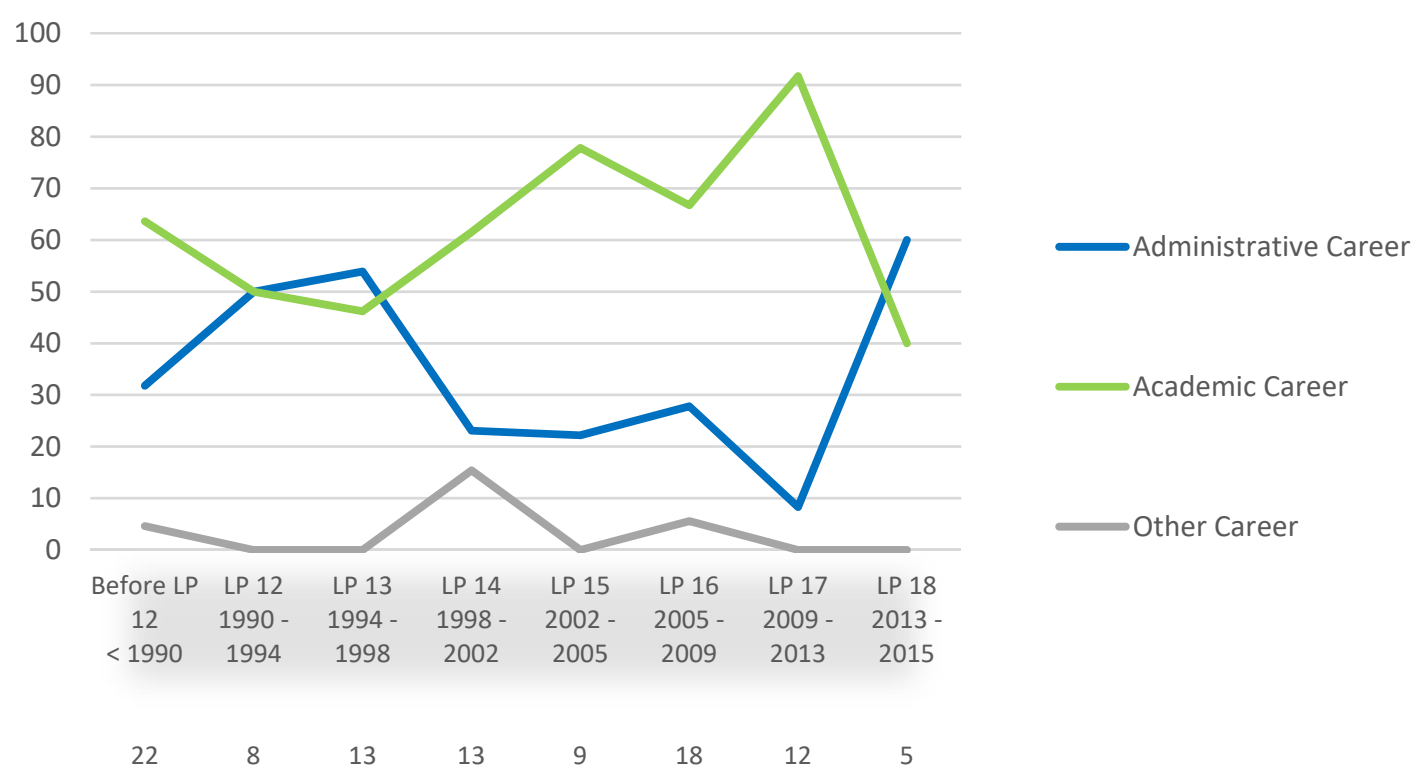

Notes: The dataset covers all CEO which held office between 1990 and (mid) 2015. This also includes individuals appointed before 1990 who were still in office in 1990. Academic Career includes outsider recruitment, mixed administration/academia, mixed academia/other sector. Administrative Career includes civil service and mixed administrative careers. Other career refers to a career outside public administration and academia. Numbers below: Absolute number $(\mathrm{N})$ of agency heads per LP.

Source: Own data.

\section{Figure 4: Previous position of chief executives of research agencies (\% of all CEO per LP)}

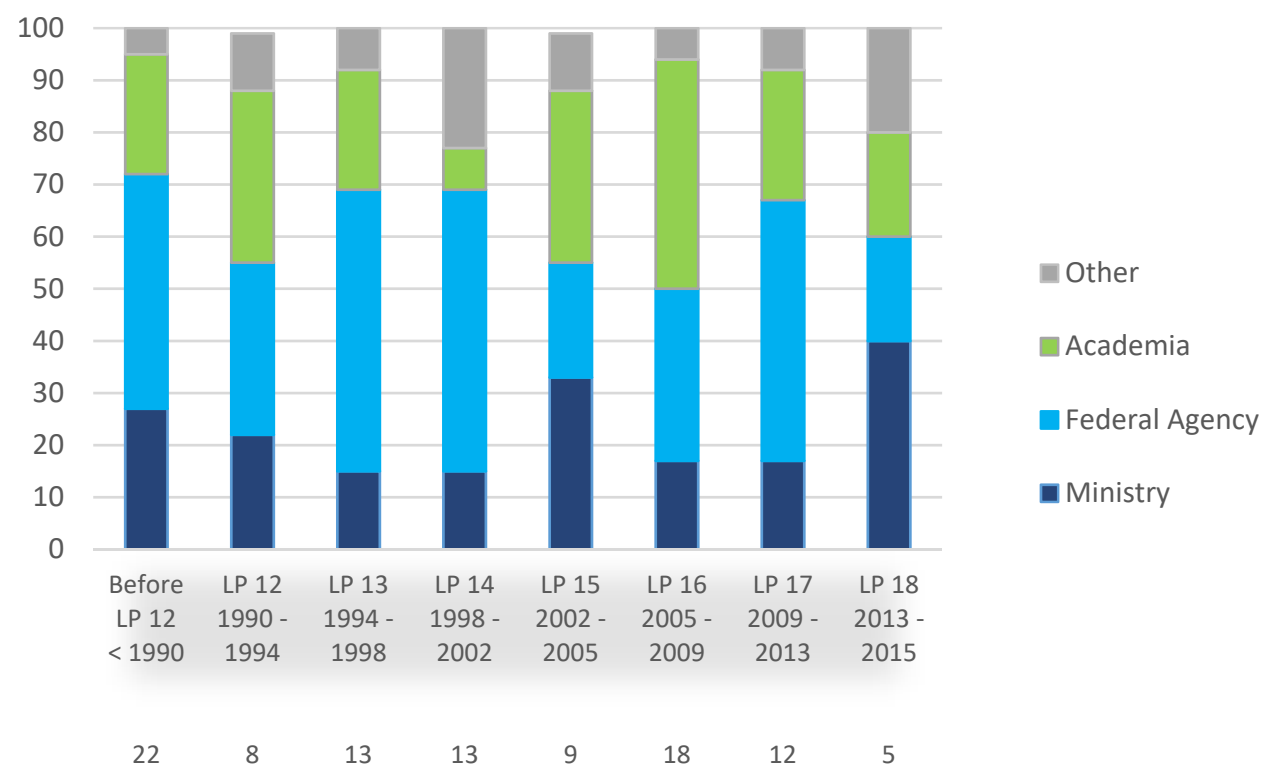

Notes: The dataset covers all CEO which held office between 1990 and (mid) 2015. This also includes individuals appointed before 1990 who were still in office in 1990. Numbers below: Absolute number $(\mathrm{N})$ of agency heads per LP. Source: Own data. 
Figure 5: Formal mandates of advisory bodies 1990-2015 (absolute numbers)

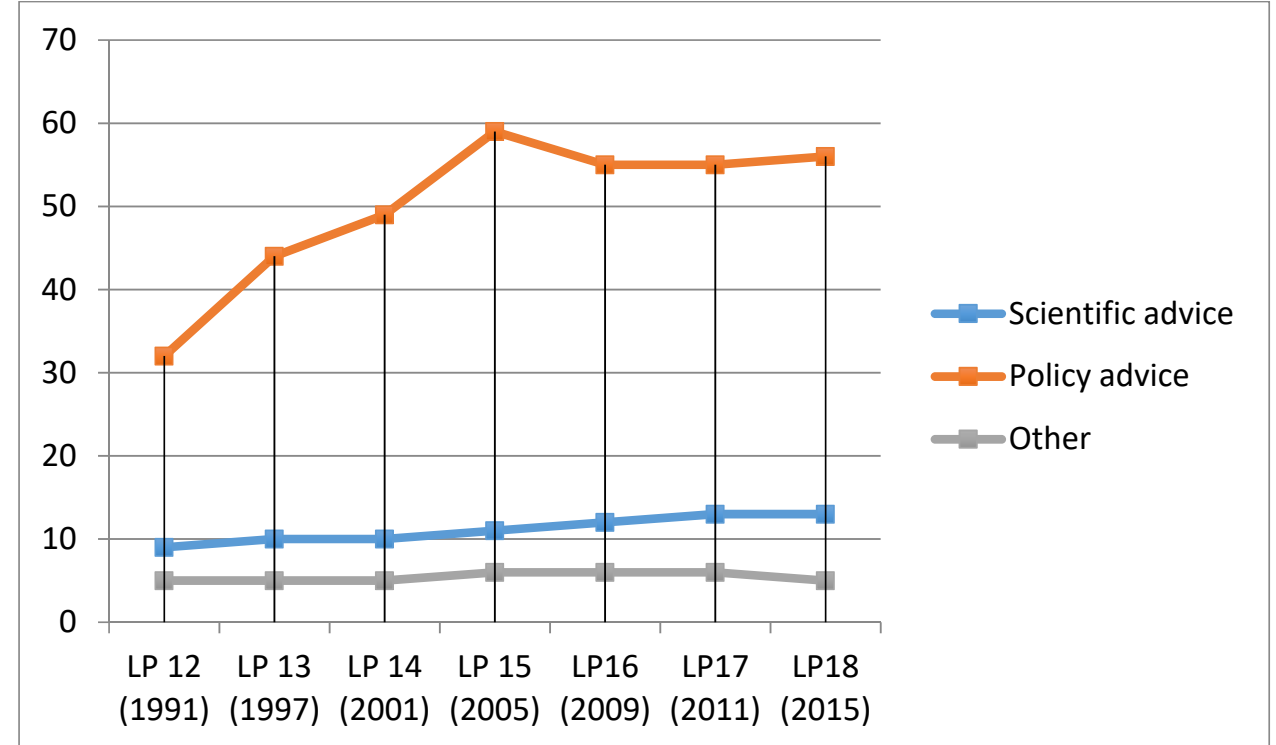

Note: 'Others' refers to the few bodies that are considered to advice the government by preparing single decisions. Numbers below: Absolute number $(\mathrm{N})$ of agency heads per $\mathrm{LP}$.

Source: Own data.

\section{Figure 6: Composition of advisory bodies (absolute numbers)}

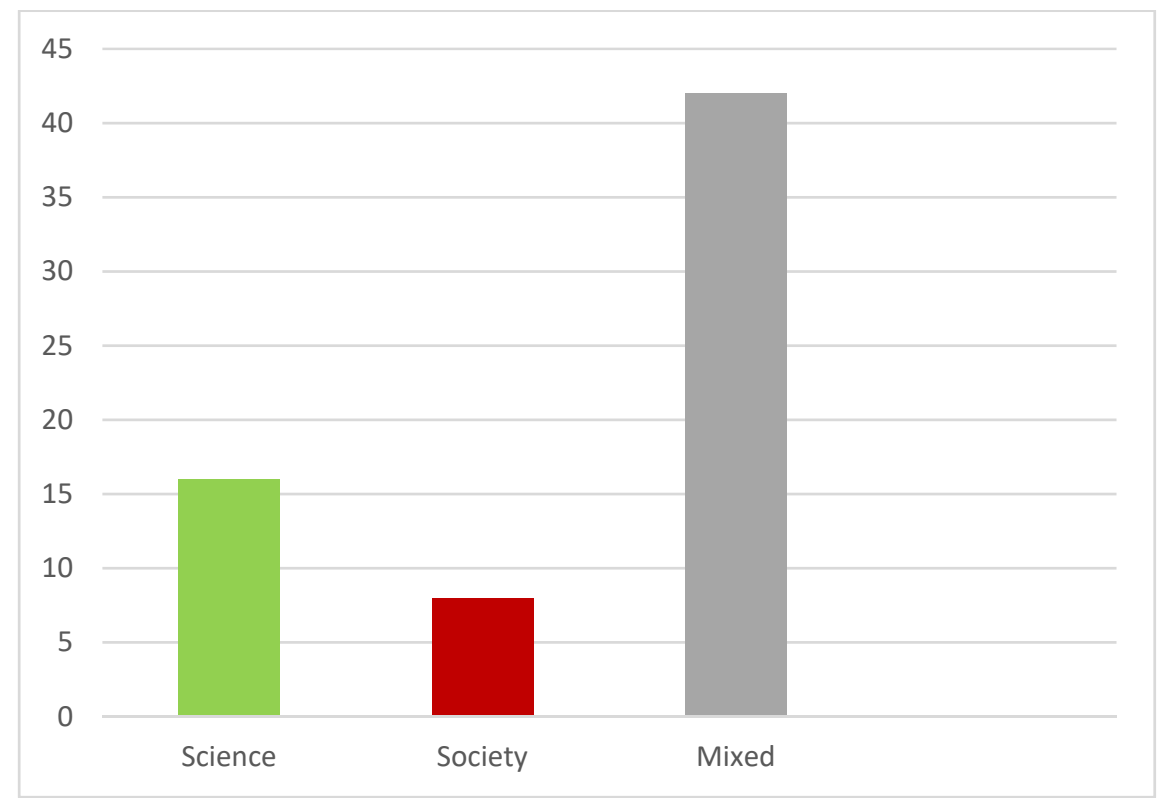

Notes: Fig. 6 depicts as of 2015 if members of advisory bodies are from academia ('science'), or if members do represent societal organizations (includes administrative representatives, but excludes academics) or if advisory bodies are staffed with a mix of members from science, societal organizations and/or administration (at least one scientific member in 2015). This table includes only those bodies that are still in existence in 2015, for which individual level data could be gained. Thus, there are differences in the total $\mathrm{N}$ included here and in figure 5 above.

Source: Own data. 